\title{
ELECTROPHORETIC CHARACTERIZATION OF OUTER MEMBRANE PROTEIN EXTRACT FROM ESCHERICHIA COLI ISOLATED FROM GOAT MILK IN EGYPT
}

\author{
*Hoda Abd El-Monem; H.S. Nada and ${ }^{* *}$ S. M. Nada \\ *Animal Health Research Institute, Dokki, Egypt \\ ${ }^{* *}$ Faculty of Vet. Med., Tanata Univ., Kafr El-Sheikh branch
}

\begin{abstract}
Outer membrane protein (OMP) extracts of two E. coli strains O125 and 0178 isolated from goat milk were purified and analyzed by use of sodium dodecyl sulphate polyacrylamide gel electrophoresis (SDSPAGE). Each strain showed a distinct electrophoretic profile. Minor difference in profiles within strains showed the existence of different biotypes. It is concluded that SDS- PAGE may be used in the characterization and strain differentiation. The outer membrane protein extract from strain I revealed 2 distinct bands between 29.0 and $44.4 \mathrm{KD}$. On the other hand, the outer membrane protein extract for strain II revealed 3 distinct bands between the same range of molecular weight.
\end{abstract}

\section{INTRODUCTION}

Escherichia coli is one of the main etiological agents of mastitis in goats and one of the most serious causes of death losses in livestock. Several previous studies have focused on the whole cell protein. However, little is known about the outer membrane protein (OMP) of the organism. Analysis of OMP of several other gram negative pathogens has resulted in the identification of proteins that have been useful as epidemiologic and virulence markers (Achtman et al., 1983 and Granoff et al., 1982).

Therefore the objective of this study reported here was to examine the sodium dodecyl sulfate polyacrylamide gel electrophoresis (SDSPAGE) profile of OMP- enriched extracts of 2 serotypes of E. coliO125 and 0178 .

Kafr El-Sheikh Vet. Med. J. Vol. 3 No. 1 (2005) 


\section{MATERIAL AND METHODS}

\section{Bacterial strains and growth conditions:}

Milk samples and blood samples were collected from a flock apparently healthy strains $\mathrm{O} 125$ and O178 Bacterial strain of E.coli isolated from she-goat mastitic dairy goats at Giza Governorate.

Milk samples were investigated for bacterial isolates by biochemical identification according to Cruickshank et al., (1975) and Quinn et al., (1994).E. coli strains were grown at 37c on Maconkey's bile salt neutral red lactose agar. The organisms were preserved on Dorset egg medium and subculture was done in soft agar $\mathrm{pH}$ 7.2- 7.4. blood samples were centrifuged to obtain clear sera from serological tests as shown in table 1 (Abdel El Ghaffar et al. 1970,Engvall 1971 and Alton et al.1988).

\section{Preparation of outer membrane protein (OMP) enriched extracts:}

Sodium lauryl sarcosinate detergent- insoluble OMP- enriched fraction were prepared by the method of Barenkamp et al., (1981). Briefly, cells were harvested and washed twice with $0.85 \% \mathrm{NaCl}$ and suspended in $10 \mathrm{mM}$ HEPES buffer ( $\mathrm{pH} 7.4)$, and disrupted 4 times while cooling in an ice bath, using a sonicator for 30 seconds. Intact cells and large debris were removed by centrifugation at $1700 \mathrm{xg}$ for 20 minutes. The supernatant was centrifuged at $100.000 \mathrm{xg}$ for 60 minutes at $4{ }^{\circ} \mathrm{C}$. The pellet, which contained total membrane, was resuspended in $2 \mathrm{ml}$ of $2 \%$ sodium lauryl membrane. Enriched fraction was sedimented by centrifugation at $100.000 \mathrm{xg}$ for 60 minutes at $4{ }^{\circ} \mathrm{C}$ and then washed 2 times with distilled water, dialyzed against distilled water for 48 hours, lyophilized, and then stored at $-20^{\circ} \mathrm{C}$.

\section{Sodium dodecyl sulfate - polyacy lamide gel electrophoresis:}

The OMP-enriched fraction prepared from two strains of E.coli were subjected to discontinuous SDS-PAGE according the method of Laemmli (1970). Prior to loading onto the gel, the OMP- enriched fractions were heated at $100{ }^{\circ} \mathrm{C}$ for 4 minutes in samples buffer containing 0.06 MTris, $1.2 \%$ SDS, $5 \%$ B-mercaptoethanol, and $11.9 \%$ glycerol. Sample containing $15 \mu \mathrm{g}$ of protein in 5o $\mu \mathrm{l}$ of samples buffer was loaded into each Kafr El-Sheikh Vet. Med. J. Vol. 3 No. 1 (2005) 
lane. The protein content of the sample was determined by the modified Lowery procedure of Markwell et al., (1978). The OMP of E. coli was separated on SDS-polyacrylamide slab gels using Heofer mini-gel system (SE 250, Mighty small II) with PS 500 XT power supply. The completed gel used in this study consisted of a stacking and a separating gel. The stacking gel contained final concentration of 4\%acrylamide/ $\mathrm{N}$ methylene - bisacrylamide (SIGMA), $0.125 \mathrm{M}$ Tris- $\mathrm{HCl}$ (pH 6.8) and 10\% (W/V) SDS. The separation gel contained $12 \%$ acrylamide $\mathrm{N}$-methylene bisacrylanide, $0.375 \mathrm{M}$ Tris. $\mathrm{HCl}(\mathrm{pH} 8.8)$ and 10\% (W/V)SDS. Polymerization was achieved by the addition of $0.05 \%(\mathrm{~V} / \mathrm{V}) \mathrm{N}, \mathrm{N}, \mathrm{N}, \mathrm{N}-$ tetramethylenediamine (TEMED) and $0.05 \%$ (W/V)ammonium persulphate (SIGMA). The elec-trophoresis buffer ( $\mathrm{pH} 8.3$ ) consisted of $0.025 \mathrm{M}$ tris base,0.192 $\mathrm{M}$ glycine and $0.1 \%$ SDS.

Electrophoresis was performed at room temperature at a constant voltage of $120 \mathrm{~V}$ until the bromophenol blue dye reached $1 \mathrm{~cm}$ from the bottom.Gels were stained with coomassie blue R-250. Molecular weights were estimated from a linear least-squares fit of the logarithm of molecular weight versus relative mobility of the standards. The standard error of the estimate for these plots was generally less than or equal $2 \pm \mathrm{Kda}$.

A mixture of molecular weight standards (SIGMA chemical Co.) were prepared at a concentration of $4 \mathrm{mg} / \mathrm{ml}$ in SDS sample buffer,and $10 \mu \mathrm{l}$ were applied to the gel. The standards were: bovine serum albumin (64 KDa), ovalbumin (44 KDa),glyceraldehydes-3- phosphate dehydrogenase $(36 \mathrm{KDa})$, carbonic anhydrase $(29, \mathrm{KDa})$, trypsinogen $(24 \mathrm{KDa})$, Soybean tryspin inhibitor(20 KDa), $\beta$-lactalbumin(18 KDa)and lysozyme (14 KDa).

\section{RESULTS AND DISCUSSION}

SDS- PAGE analysis of major polypeptides from outer membrane of two strains of $E$. coli were visualized by coomassie staining. The protein profile of each Strain O125,O178 is represented in Fig. (1).

$\overline{\text { Kafr El-Sheikh Vet. Med. J. Vol. } 3 \text { No. } 1 \text { (2005) }}$ 


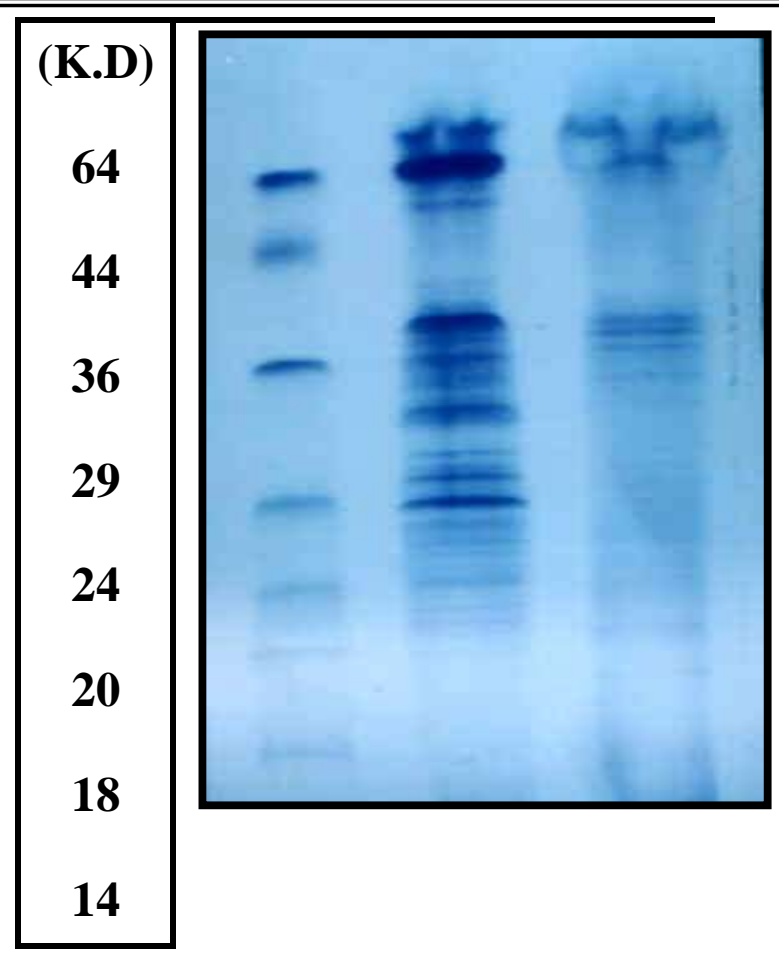

Fig. (1): SDS- PAGE analysis of outer membrane protein enriched extract of two E. coli strains.

1) Molecular weight marker.

2) Strain 0125 .

3) StrainO178.

Table (1): Serological detection for E. coli in good:

\begin{tabular}{|c||c|c||c|c||c|c||}
\hline \multirow{2}{*}{$\begin{array}{c}\text { No of blood } \\
\text { samples }\end{array}$} & \multicolumn{2}{|c||}{ Eliza test } & \multicolumn{2}{c||}{ Agglutination } & \multicolumn{2}{c|}{$\begin{array}{c}\text { Complement } \\
\text { fixation test }\end{array}$} \\
\cline { 2 - 7 } & No + Ve & $\%$ & No + Ve & $\%$ & No + Ve & $\%$ \\
\hline \hline 125 & 7 & 6.5 & 6 & 4.8 & 5 & 4 \\
\hline
\end{tabular}

The outer membrane protein extract from strain O125 (Fig.1 lane 2) revealed two distinct bands between 29 and $44 \mathrm{KD}$. On the other hand,

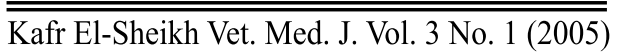


the outer membrane protein extract for strain O178(Fig.1 lane3) revealed three distinct bands between the same range of molecular weight. There is a minor difference in profiles, existence of different biotypes.

In this study, a mild anionic detergent was used, sodium lauryl sarcosinate, for extraction of the OMP from E. coli strains. Other methods are available for extraction of OMP from gram- negative bacteria. Stull et al., (1985) compared the SDS- PAGE electrophoresis of OMP extracted from gram-negative bacteria by use of various kinds of detergents and found that the OMP obtained from Triton X-100 and lithium extractions closely approximated that isolated by use of isopykinc centrifugation.

Sodium dodecyl sulfate-polyacrylanide gel electrophoresis was used to examine the OMP profiles of 2 strains of $E$. coli isolated from goats suffered from mastitis. The protein profiles of OMP-enriched extract were remarkably similar except for minor quantitative differences.

The important aspect of this study was expressed as strain- specific OMP, which can be used as markers to identify the strains. The expression of these OMP markers was stable and reproducible.

Brogdan and Rimler(1982 and 1983)reported that the immunogen termed cross- protection factor was present in the outer membrance and that the cross-protection factor was indeed responsible for cross immunity against homologous and heterologous serotypes of E. coli.

Most epidemiologic and immunoprophylaxis research in E. coli infections have relied on serotyping for strain classification. Because serotyping does not accurately differentiate between strains, this would be useful and would provide valuable information. However, we realize that additional studies, using OMP-enriched fractions from a considerable number of isolates, need to be analyzed by SDS-PAGE before the recommendation of this technique to differentiate between the different isolates of $E$. coli that are of the same serotype.

\section{REFERENCE}

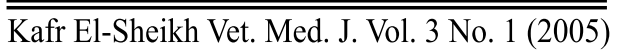


- Abdel-El Ghaffar, M. M. l,Mahmoud,M.Sh.and Nada,S.M. (1970): Evaluation of the different diagnostic serological tests for brucellosis among cattle. $9^{\text {th }}$ Vet.Congress,Cairo, 1970.

- Achtman,M.A.,Mercer,B. and Kusecek, A. (1983): "Six widespread bacterial clones among Escherichia coli K1 isolates".Infect. Immun;39: 315-335.

- Alton G.G.; jones, L.M., Angus. R; D. Verger J.M.(1988): Techni-quies for the Brucellosis laboratory Institute National de La Recherche Agronomique Paris ,France.

- Barenkamp, S. J.; Munson, R. S. and Granoff, D. M. (1981): Subt-yping isolates of Haemophilus influenza type b by outmembrane pro-tein profiles". J. Infect. Dis, 143: 668-676.

- Brogden, K. A. and Rimler, R. B. (1983): "Lysates of turkeygrown Pasteurella multocida:effects of solubilizing agents on the immunologic properties of membrane vesicles. Am. J. vet. Res. ; 44: 428-432.

- Ibid (1982): "Lysates of turkey- grown Pasteurella multocida: Partial solubilization of the cross- protection factor (s). Am. J. Vet. Res.; 43: 1781-1785.

- Cruickshank, B.; Duguid, J. B.; Marmion, L. S. and Swain, R. H. A. (1975): Medical Microbiology" 12ed. Churchill Living stone, Edin-burg and New York. Laemmli, U.K. (1970): "Cleavarge of structural protein during the assembly of the head of bacteriophage T4. Nature (London) 1970; 227: 680685 .

- Engvall, E. and P.Perlmann(1971): Enzyme -linked Immunosorbent assay (ELISA), Quantitative assay of Immunoglobulin G.Immunoche-mistry 8:871-874 
- Granoff,D. M.; Barenkamp, S. J. and Munson, R.S. (1982): "Outer membrane protein subtypes for epidemiologic investigation of Haem-ophilus influenzae type B disease". In: sell SH, Wright PF,eds. Haem-ophilus Influenzae: "epidemiology immunology and prevention of disease". New York: Elservier- Science publishing Co.: 43-54.

- Laemmli,u.K,: cleavage of structural protins during the assembly of the head of bacteriophage T4 . Nature,227: 680685,1970 .

- Markwell, M. A. K.; Haas, S. M.; Bieder, L.L. and Tolbert, N. E. (1978): "Modification of the Lowry procedure to simplify protein determination in membrane and lipoprotein samples". Anal. Biochem. 87: 206-210.

- Quinn, P. J.; Carter, M. E., Markey, B. and Carter, G. R. (1994): "Clinical Veterinary Microbiology, Mosby Europe limited, London, England.

- Stull, T. L.; Mack, K. and Gordon J. (1985): A comparison of tech-niques for isolation of the outer membrane protein of Hoemophilus influenza type. b. Anal. Biochem; 150: 471480.

$$
\begin{aligned}
& \text { التوصيف الكهربى للبروتين السطحى المستخلص من الميكروب القولونى المعزول من }
\end{aligned}
$$

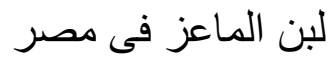

$$
\begin{aligned}
& \text { هلى عبد المنعم * وهشام سعد ندا*** و سعد ندا* } \\
& \text { "معهز بحوث صحة الحيوان بالدقى }
\end{aligned}
$$

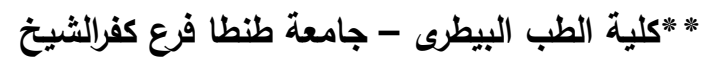

$$
\begin{aligned}
& \text { تم إجراء التحليل للبروتين السطحى (الخارجى) لعترتين من من الميكروب القولونى } \\
& \text { والمعزول من لبن الماعز المصابة بالتهاب الضرع ووجد ان هناك اختلافات بسيطة داخل كل عترة مما لهاء } \\
& \text { يؤكد وجود عترات مختلفة وهذا يدل على أهمية الفصل الكهربى للتوصيف والتفريق بين العترات }
\end{aligned}
$$


Electrophoretic Characterization Of Outer Membrane ... $\quad$ Hoda Abd El-Monem; H.S. Nada., et.al.

المختلفة حيث تبين بالنسبة للعثرة الأولى وجود شريطين واضحين من عديد البييتيد بينما فى العترة

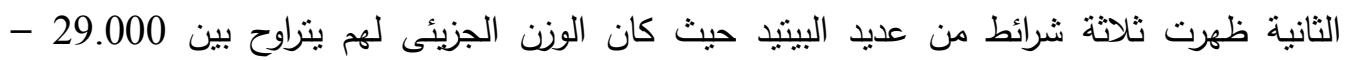
44.400 كيلو دالتون. 